\title{
PENGARUH PERENCANAAN TENAGAKERJA, LINGKUNGAN KERJA TERHADAP PENINGKATAN KUALITAS PRODUK LAYANAN PERBANKAN SYARIAH
}

\author{
Elan Eriswanto, Tina Kartini \\ r_land_smi@yahoo.co.id, thienazahira@gmail.com \\ Universitas Muhammadiyah Sukabumi
}

\begin{abstract}
The goals of research is to determine the effect employee planning anad working of environment the quality product services syariah banking at Sukabumi. This study using variables employee planning, working environment and the quality product service.

This research using associative method with a quantitative approach. The intrumens questionnaires distributed 156 respondents. Sampling method used purposive by percentage, the data analysis method regression test, test $f$ and the coefficient of determination.

The results this study shows that employee planning has minimum influence to the quality product services and working environment has effect on the quality product services. Based on the results of research show that the test $f$ employee planning and working environment effect on the quality product services.
\end{abstract}

\section{Key words : Employee planning, working environment and quality product services}

\section{Pendahuluan}

Berdasarkan hasil studi pendahuluan yang dilakukan terhadap perkembangan perbankan berbasis syariah yang cukup pesat beberapa tahun terakhir menunjukkan keinginan publik terhadap ekonomi syariah terus mengalami peningkatan. Hal ini tercermin dari pertumbuhan asset, peningkatan pembiayaan, ekspansi pelayanan, jaringan kantor yang semakin meluas menjangkau 34 propinsi di Indonesia.

Pertumbuhan tersebut patut kita syukuri dengan terus membenahi beberapa kendala yang dapat menghambat perjalanan industri keuangan syariah ke depan. Harus kita akui saat ini perbankan syariah masih memiliki banyak rintangan yang harus direspons dengan baik.

Ternyata terdapat beberapa masalah berkenaan dengan minimnya SDM yang bertalar belakang syariah. Universitas Indonesia (UI) melakukan riset terkait krisis SDM yang menimpa industri keuangan syariah. Hasil riset menyebutkan bahwa kurang lebih 90 persen SDM bank syariah tidak memiliki latar belakang pendidikan ekonomi syariah. Saat ini pun SDM syariah yang berada di beberapa lembaga keuangan syariah masih relatif sedikit. Sebab output perguruan tinggi belum mampu memenuhi permintaan pasar yang begitu besar. Kenyataan menunjukkan kecenderungan-kecendrungan sebagai berikut:

1. Bank Syariah pada kenyataan nya tidak banyak menerapkan sistem bagi hasil mudharabah ataupun musyarakah. Kondisi tersebut dapat terlihat pada besarnya skim pembiayaan atas dasar jual beli (murabahah). Ini tentunya menyebabkan predikat Bank Syariah sebagai Bank "Bagi hasil" tidak berjalan optimal. Mengakibatkan produk perbankan syariah yang mereka tawarkan tidak memiliki kualitas yang seharusnya bank syariah terapkan.

2. Perbankan Syariah sangat perlu SDM yang handal, terbukti dari masih banyaknya SDM Perbankan Syariah yang berasal dari Bank Konvensional, ini menyebabkan kurangnya kualitas 
perbankan Syariah dari segi kualitas produk yang sesuai dengan prinsipprinsip Syariah yang sebenarnya. Sumber Daya Manusia yang ada di Bank Syariah belum bisa memberikan informasi dengan sebenar-benarnya dan sejelas-jelasnya tentang Produk yang mereka tawarkan sehingga nasabah tidak mendapatkan informasi yang optimal.

3. Dari segi pelayanan Bank Syariah belum bisa melaksanakan tugasnya dengan baik, dikarenakan dipengaruhi lingkungan kerja yang kurang memadai dari berbagai segi sehingga kurang mencirikan bank syariah yang seharusnya.

Padahal, secara teoritis, seharusnya:

1. Menurut Tarsidin (2010) berpendapat bahwa dari skema bagi hasil diatas, skema profit sharing (profit and loss sharing) merupakan bentuk skema bagi hasil yang seharusnya digunakan pada perbankan syariah dalam pembiayaan mudharabah dan musyarakah. Hal senada diungkapkan oleh Chapra bahwa adanya ijma menentang bunga sudah tentu mengantarkan kepada pembicaraan tentang sebuah alternatif terhadap sistem intermediasi keuangan modern yang berbasis bunga. Sistem yang diajukan ini dimaksudkan untuk lebih banyak mengandalkan pada modal sendiri (equity) dan sedikit pada kredit, yang terdiri dari kombinasi model-model primer seperti mudharabah (kemitraan pasif), musyarakah (kemitraan aktif). Dan model model sekunder seperti murabahah (cost plus service charge), ijarah (sewa), ijarah wa iqtina (sewa beli), salam (forward delivery contract), dan istina'(contracted production).

2. Dalam penyiapan SDM berbasis syariah, di samping adanya persyaratan keilmuan dan keterampilan yang berlaku secara umum, ada lagi persyaratan khusus yang sangat menentukan. Sesuai dengan kerangka filosofis ekonomi syariah seperti yang telah diuraikan pada bahagian awal, perusahaan yang berbasis syariah sejatinya harus dikelola dengan hati. Dalam buku "Marketing Syariah" karya Hermawan Kartajaya dan Muhammad Syakir Sula, ditegaskan bahwa dalam mengelola bisnis syariah perlu dilakukan dengan qalbu. Tawaran ini nampaknya dapat dijadikan acuan dalam menyiapkan SDM yang handal sebagai pondasi berkembangnya ekonomi syariah. Penyiapan SDM ini sudah barang tentu akan lebih efektif kalau dilakukan melalui lembaga pendidikaan di Perguruan Tinggi dan mungkin juga dengan pelatihanpelatihan yang memadai.

3. Lingkungan kerja dalam suatu perusahaan merupakan salah satu hal yang sangat penting untuk diperhatikan. Meskipun lingkungan kerja tidak melaksanakan proses operasional secara langsung tetapi lingkungan kerja berpengaruh langsung terhadap karyawan yang melaksanakan proses operasional perusahaan tersebut. Menurut Alex S Nitisemito (2000:183) yang mendefinisikan lingkungan kerja sebagai berikut: " Lingkungan kerja adalah segala sesuatu yang ada disekitar para pekerja yang dapat mempengaruhi dirinya dalam menjalankan tugas-tugas yang diembankan".

Berdasarkan uraian hal tersebut di atas, maka dapat dirumuskan masalah penelitian sebagai berikut:

a. Bagaimana pengaruh Perencanaan Tenaga Kerja terhadap Kualitas Produk Layanan Perbankan Syariah

b. Bagaimana pengaruh Lingkungan Kerja terhadap Kualitas Produk Layanan Perbankan Syariah

c. Bagaimana pengaruh Perencanaan Tenaga Kerja dan Lingkungan Kerja terhadap Kualitas Produk Layanan Perbankan Syariah

\section{Landasan Teori}

Milkovich dan Nystrom (Yoder, 1981:173), mendefinisikan perencanaan tenaga kerja sebagai berikut : 
"Manpower planning is the process (including forecasting, developing, implementing, and controlling) by which a firm ensures that it has the right number of people and the right places, at the economically most useful".

Bedasarkan definisi tersebut dapat disimpulkan bahwa perencanaan tenaga harus mencakup proses peramalan, pengembangan, pengimplementasian dan pengontrolan yang menjamin perusahaan mempunyai kesesuaian jumlah pegawai, penempatan pegawai secara benar, waktu yang tepat, yang secara otomatis lebih bermanfaat.

"Perencanaan sumber daya manusia adalah proses analisis dan identifikasi tersedianya dan kebutuhan akan sumber daya manusia sehingga organisasi tersebut dapat mencapai tujuan" (Robert L.Mathis dan Jhon H.Jackson;2001). Menurut Handoko

(1997:53)

Perencanaan sumber daya manusia atau perencanaan tenaga kerja merupakan serangkaian kegiatan yang dilakukan untuk mengantisipasi permintaan-permintaan bisnis dan lingkungan pada organisasi di waktu yang akan datang dan untuk memenuhi kebutuhan-kebutuhan tenaga kerja yang ditimbulkan oleh kondisi-kondisi tersebut. Di mana secara lebih sempit perencanaan sumber daya manusia berarti mengestimasi secara sistematik permintaan (kebutuhan) dan suplai tenaga kerja organisasi di waktu yang akan datang.

Pandangan lain mengenai definisi perencanaan sumber daya manusia dikemukakan oleh Mangkunegara ( 2003:6) Perencanaan tenaga kerja dapat diartikan sebagai suatu proses menentukan kebutuhan akan tenaga kerja berdasarkan peramalan pengembangan, pengimplementasian, dan pengendalian kebutuhan tersebut yang berintegrasi dengan perencanaan organisasi agar tercipta jumlah pegawai, penempatan pegawai yang tepat dan bermanfaat secara ekonomis.Lingkungan kerja.

Menurut Sedarmayati (2009:21)Lingkungan Kerja adalah keseluruhan alat perkakas dan bahan yang dihadapi, lingkungan sekitarnya dimana seseorang bekerja, metode kerjanya, serta pengaturan kerjanya baik sebagai perseorangan maupun sebagai kelompok. Menurut Alex S. Nitisemito (2000:183) mendefinisikan lingkungan kerja sebagai berikut: " Lingkungan kerja adalah segala sesuatu yang ada disekitar para pekerja yang dapat memperngaruhi dirinya dalam menjalankan tugas-tugas yang diembannya.

Menurut Schultz (2007) lingkungan kerja diartikan sebagai suatu kondisi yang berkaitan dengan ciri-ciri tempat bekerja terhadap perilaku dan sikap pegawai dimana hal tersebut berhubungan dengan terjadinya perubahan-perubahan psikologis karena hal-hal yang dialami dalam pekerjaannya atau dalam keadaan tertentu yang harus terus diperhatikan oleh organisasi yang mencakup kebosanan kerja, pekerjaan yang monoton dan kelelahan. Dari beberapa pendapat diatas dapat disimpulkan bahwa lingkungan kerja merupakan segala sesuatu yang ada disekitar karyawan pada saat bekerja yang dapat memperngaruhi dirinya dan pekerjaan nya saat bekerja.

\section{Kualitas layanan}

Kualitas Produk adalah suatu kondisi dinamis yang berhubungan dengan produk, manusia atau tenaga kerja, proses serta lingkungan yang mematuhi atau melebihi harapan pelanggan atau konsumen. Dimensi-dimensi dari kualitas produk menurut Aaker (1991) dan Keller(1998) :

1) Performance, tingkat dimana karakteristik utama produk beroperasi.

2) Feature, elemen kedua dari produk yang merupakan komplemen dari karakteristik utama produk.

3) Comformance quality, derajat dimana produk memenuhi spesifikasi dan bebas dari cacat.

4) Realibility, kekonsistenan dari kinerja setiap waktu dan dari pembelian ke pembelian.

5) Durability, harapan terhadap umur hidup produk. 
6) Serviceability, kemudahan dari produk untuk diservis.

7) Style and Design, penampilan atau perasaan orang terhadap kualitas produk.

Menurut David Garvin yang diterjemahkan oleh Husein Umar (2002:147) ada delapan dimensi produk yang dapat digunakan untuk menganalisis karakteristik kualitas barang, yang tentunya banyak ditetapkan oleh perusahaan yaitu sebagai berikut :

1. Kinerja (performance)

Dimensi ini merupakan yang paling dasar dan berhubungan dengan fungsi utama dari suatu produk. Artinya seberapa baik suatu produk melakukan apa yang seharusnya dilakukan. Konsumen akan sangat kecewa apabila harapan mereka akan dimensi ini tidak terpenuhi. Bagi setiap produk, yang namanya kinerja ( performance) bisa berlainan, tergantung dari nilai fungsinya ( fungtional value ) yang dijanjikan oleh perusahaan. Jadi indikator-indikator dari kinerja yang akan diteliti untuk produk Poldan Mig antara lain adalah operasional produk Poldan Mig dan komposisi produk Poldan Mig.

2. Dimensi Keistimewaan Tambahan ( feature )

Dimensi ini dapat dikatakan sebagai aspek sekunder karena dimensi ini menerangkan pernik-pernik yang melengkapi dan meningkatkan fungsi dasar produk, karena perkembangan dimensi ini hampir tidak ada batasnya. Seiring dengan perkembangan teknologi saat ini, maka dimensi ini menjadi target para produsen untuk berinovasi dalam upaya memuaskan pelanggan yang akhirnya pelanggan menjadi loyal. Jadi indikator-indikator dari dimensi keistimewaan tambahan yang akan diteliti untuk produk Poldan Mig antara lain adalah kualitas bahan obat generik.

3. Kehandalan ( reliability)

Dimensi ini lebih menunjukan probabilitas adalah kemungkinan produk gagal menjalankan fungsinya. Hal ini berarti bahwa kualitas berkaitan dengan kemampuan produk untuk bertahan selama penggunaan biasa. Jadi indikator-indikator dari dimensi kehandalan yang akan diteliti untuk produk Poldan Mig antara lain adalah cara kerja obat generik dalam kemasan.

4. Keawetan (durability)

Dimensi ini menunjukan suatu pengukuran terhadap suatu siklus produk, baik secara teknis maupun waktu. Produk ini disebut awet apabila sudah banyak digunakan atau sudah lama digunakan konsumen, awet yang berhubungan dengan aspek yang lebih mudah dimengerti, karena itu sebagian besar produk-produk yang menjanjikan keawetan lebih menonjolkan masalah awet adalah hal waktu. Jadi indikatorindikator dari dimensi keawetan yang akan diteliti untuk produk Poldan Mig antara lain adalah daya tahan produk ketika dikonsumsi dalam arti masa pakai produk.

5. Kesesuaian ( conformance)

Dimensi ini menunjukan seberapa jauh suatu produk dapat menyamai standar atau spesifikasi tertentu. Produk yang mempunyai kesesuaian tinggi berarti produknya sesuai standar yang telah ditentukan. Jadi indikator-indikator dari dimensi kesesuaian yang akan diteliti untuk produk Poldan Mig antara lain adalah komposisi produk Poldan Mig yang diharapkan/ yang dijanjikan yang sesuai dengan CPOB ( cara pembuatan obat yang baik ).

6. Dimensi Keindahan (aesthetic)

Dimensi ini menunjukan bagaimana suatu produk dapat dilihat dan dirasakan secara langsung. Hal ini dikarenakan sebagian orang membeli suatu produk bukan karena kinerja atau keistimewaan lainnya tetapi berdasarkan kualitas produk tersebut. Jadi indikator-indikator dari dimensi keindahan yang akan diteliti untuk produk Poldan Mig adalah keindahan warna kemasan. 
7. Dimensi Kemudahan Perbaikan ( serviceability )

Dimensi ini meliputi kecepatan, kenyamanan, mudah kualitas yang dipersepsikan direparasi, serta penanganan keluhan yang memuaskan. Jadi indikator-indikator dari dimensi kemudahan perbaikan yang akan diteliti untuk produk Poldan Mig antara lain adalah pelayanan purna jual apabila produk tidak sesuai ( cacat ) dan biasanya hancur ketika dicetak.

8. Dimensi Kualitas yang Dipersepsikan ( perceived quality )

Dimensi ini menunjukan citra dan reputasi produk serta tanggung jawab perusahaan terhadap produk tersebut. Jadi indikator-indikator dari dimensi kualitas yang dipersepsikan yang akan diteliti untuk produk Poldan Mig antara lain adalah kualitas yang dipersepsikan dan reputasi yang baik terhadap produk Poldan Mig tersebut.

Berdasarkan kajian teori, hasil penelitian sebelumnya dan permasalahan yang dikemukakan, maka sebagai acuan untuk merumuskan hipotesis, berikut disajikan kerangka pemikiran teoritis yang dituangkan dalam model penelitian seperti yang ditunjukkan pada gambar berikut:

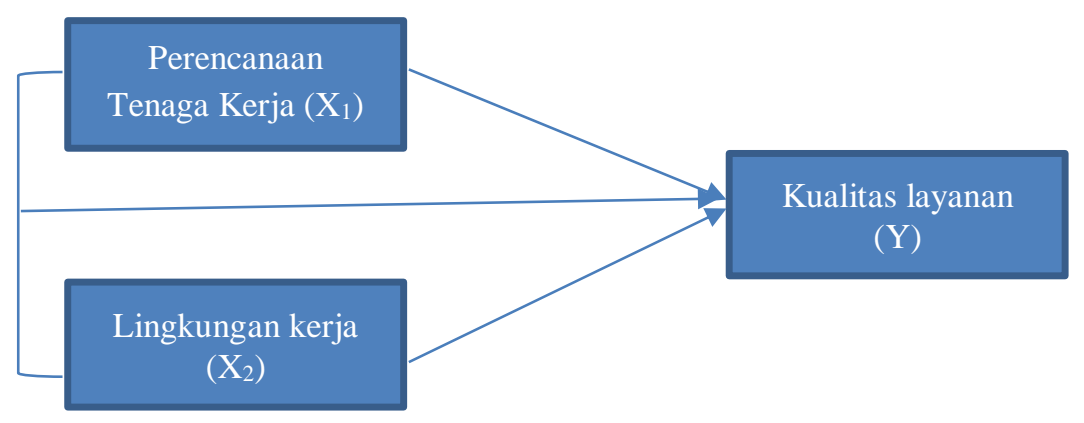

Gambar 1

Kerangka Pemikiran Teoritis

\section{Metode Penelitian}

Penelitian ini menggunakan objek Perbankan syariah yaitu perencanaan tenaga kerja, lingkungan kerja dan kualitas produk layanan.

Adapun jenis penelitian yang digunakan adalah penelitian asosiatif atau hubungan dengan pendekatan kuantitatif. Penelitian asosiatif merupakan penelitian yang bertujuan untuk mengetahui hubungan antara dua variabel atau lebih. Data kuantitatif adalah data yang terbentuk angka atau data kualitatif yang dijadikan angka. Dalam Penelitian variabel-variabel yang digunakan dua kategori yaitu pertama variabel bebas Perencanaan Tenaga Kerja $\left(X_{1}\right)$ dan Lingkungan Kerja $\left(X_{2}\right)$, sedangkan Kualitas Produk Layanan Perbankan
Syariah sebagai variabel terikat (dependent variable, dengan notasi statistik Y).

Populasi yang digunakan dalam penelitian ini adalah Nasabah Perbankan Syariah yang ada di Kota Sukabumi dengan populasi terbatas yaitu sebanyak 1.560 orang. Penentuan nasabah perbankan syariah yang dijadikan sampel dalam penelitian ini menggunakan purposive sampling dengan persentase yaitu $10 \%$ dari jumlah populasi yaitu 156 orang.

Teknik pengumpulan data yang digunakan adalah observasi dan kuesioner. Observasi yang dilakukan dalam penelitian ini adalah serangkaian pengamatan langsung terhadap obyek yang akan diteliti sebagai suatu bahan bagi penulis untuk kemudian dianalisisMenurut Sugiyono (2013:200) "Kuesioner adalah teknik 
pengumpulan data yang dilakukan dengan cara memberi seperangkat pertanyaan atau pernyataan tertulis kepada responden untuk dijawabnya.

Analisis data yang dilakukan setelah mendapatkan data adalah tabulasi data dari hasil kuisioner. Sedangkan metode analisis data kuantitatif menggunakan program SPSS sebagai alat untuk menguji data tersebut. Sebelum dilakukan uji hipotesis maka terlebih dahulu dilakukan uji validitas dan reliabilitas. Dalam penelitian ini menggunakan analisis regresi sederhana

untuk menguji hipotesis tentang perencanaan tenaga kerja dan lingkungan kerja terhadap kualitas kerja.

\section{Hasil Penelitian Dan Pembahasan}

Berdasarkan uji validitas dan reliabilitas yang telah dilakukan dapat diketahui bahwa data valid dan reliabel, oleh karena itu data yang tersedia telah memenuhi syarat untuk menggunakan model regresi.

Tabel 1

Uji Regresi

Coefficients $^{a}$

\begin{tabular}{|cc|c|c|c|c|c|}
\hline \multirow{2}{*}{ Model } & \multicolumn{2}{|c|}{$\begin{array}{c}\text { Unstandardized } \\
\text { Coefficients }\end{array}$} & $\begin{array}{c}\text { Standardized } \\
\text { Coefficients }\end{array}$ & & \\
\cline { 2 - 5 } & $\mathrm{B}$ & Std. Error & Beta & $\mathrm{t}$ & Sig. \\
\hline 1 & (Constant) & 10.707 & 1.409 & & 7.598 & .000 \\
& X1 & -.035 & .073 & -.027 & -.477 & .634 \\
& X2 & 1.002 & .076 & .740 & 13.121 & .000 \\
\hline
\end{tabular}

a. Dependent Variable: $Y$

Berdasarkan hasil perhitungan tabel 4 di atas, maka dapat diperoleh persamaan regresi linear berganda sebagai berikut : $Y$ $=10,707-0,035+1,002$

$\begin{array}{rrrr}\text { Dimana } & \mathrm{X}_{1} & \text { : Perencanaan } \\ \text { Kenaga Kerja } & \mathrm{X}_{2} & : \text { Lingkungan } \\ & \mathrm{Y} & : & \text { Kualitas }\end{array}$

Produk Layanan

Dari persamaan regresi tersebut dapat diketahui bahwa koefisien intercept dari persamaan di atas adalah sebesar 10,707 yang mengandung pengertian bahwa pada saat perencanaan tenaga dan lingkungan kerja tetap, maka kualitas produk layanan sebesar 10,707. Dari persamaan di atas juga diketahui bahwa jika perencanaan tenaga kerja (X1) turun kualitas produk layanan akan turun sebesar 0,035 , selain itu apabila lingkungan kerja (X2) dinaikkan maka kualitas produk layanan akan naik sebesar 1,002.

Untuk lebih meyakinkan kedua variabel tersebut berkorelasi atau tidak, maka dilakukan uji $F$ dan hasilnya dibandingkan dengan $F$ Tabel. Apabila $F$ hitung lebih besar dari $F$ tabel. Maka Ho ditolak dan Ha diterima. Dalam pengujian uji $F$ ini penulis menggunakan aplikasi SPSS dalam pengujiannnya, dan hasilnya sebagai berikut:

Tabel 2

Uji F hipotesis

ANOVA $^{\mathrm{a}}$

\begin{tabular}{|cc|c|c|c|c|c|}
\hline & Model & $\begin{array}{c}\text { Sum of } \\
\text { Squares }\end{array}$ & df & $\begin{array}{c}\text { Mean } \\
\text { Square }\end{array}$ & $\mathrm{F}$ & Sig. \\
\hline 1 & Regression & 310.355 & 2 & 155.178 & 89.525 & $.000^{\mathrm{b}}$ \\
\hline
\end{tabular}




\begin{tabular}{|c|c|c|c|l|l|}
\hline Residual & 265.203 & 153 & 1.733 & & \\
Total & 575.558 & 155 & & & \\
\hline
\end{tabular}

a. Dependent Variable: $Y$

b. Predictors: (Constant), X2, X1

Dari hasil uji $F$ pada tabel 5 dapat dilihat bahwa uji $\mathrm{F}$ menunjukkan hasil sebesar 89,525 positif. Hasil pengujian dibuat sesuai kriteria pengujian yaitu membandingkan antara $\mathrm{F}_{\text {hitung }}$ dengan $\mathrm{F}_{\text {tabel }}$ pada taraf signifikan $=0,05$, df1 (jumlah variabel-1) adalah 2, dan df2(n-k-1) adalah 153. Ini berarti bahwa $F_{\text {hitung }}(89,525)>F_{\text {tabel }}$
$(3,055)$, sehingga hipotesis nol $(\mathrm{Ho})$ ditolak dan hipotesis alternative diterima $(\mathrm{Ha})$. Untuk dapat melihat seberapa besar variabel perencanaan kerja $\left(X_{1}\right)$ dan lingkungan kerja $\left(\mathrm{X}_{2}\right)$ dapat berpengaruh terhadap variabel kualitas produk layanan $(Y)$, maka koefisien determinasinya adalah

Tabel 3

Koefesien Determinasi

\begin{tabular}{|c|c|c|c|c|}
\hline \multicolumn{5}{|c|}{ Model Summary } \\
\hline Model & $\mathrm{R}$ & R Square & $\begin{array}{c}\text { Adjusted R } \\
\text { Square }\end{array}$ & $\begin{array}{l}\text { Std. Error of } \\
\text { the Estimate }\end{array}$ \\
\hline 1 & $.734^{\mathrm{a}}$ & .539 & .533 & 1.31657 \\
\hline
\end{tabular}

a. Predictors: (Constant), $\mathrm{X}_{2}, \mathrm{X}_{1}$

Dari hasil koefisien determinasi pada tabel 6 di atas, dapat dilihat bahwa koefisien determinasi menunjukkan angka sbesar 0,539 atau 53,9\%. Maka dapat ditarik kesimpulan bahwa perencanaan tenaga kerja dan lingkungan kerja memilki pengaruh terhadap kualitas produk layanan sebasar $53,9 \%$, sedangkan sisanya $46,1 \%$ dipengaruhi oleh faktor lain yang tidak diteliti.

Berdasarkan uji koefesien determinasi, dapat dilihat bahwa nilai $r$ square menunjukkan angka sebesar 0,021 atau 2,1\% maka dapat dinyatakan bahwa perencanaan tenaga kerja terhadap kualitas produk layanan memiliki pengaruh sebasar $2,1 \%$ atau dikatakan pengaruhnya lemah. Hal demikian sesuai dengan hasil observasi bahwa perencanaan tenaga kerja yang mencakup dimensi proses peramalan, pengembangan, pengimplemenasian dan pengontrolan belum sesuai dengan yang diharapkan karena pada umumnya tenaga kerja yang bekerja di bank syariah belum memiliki kompetensi yang syariah atau tidak sesuai perencanaan sehingga menimbulkan pengaruh yang lemah terhadap kualitas produk layanan perbankan syariah di Kota Sukabumi.

1. Lingkungan kerja terhadap kualitas produk layanan

Berdasarkan uji koefesien determinasi, dapat dilihat bahwa nilai $r$ square menunjukkan angka sebesar 0,539 atau $53,9 \%$ maka dapat dinyatakan bahwa lingkungan terhadap kualitas produk layanan memiliki pengaruh sebasar $53,9 \%$ atau dapat didefisikan pengaruhnya sedang. Dengan demikian bahwa lingkungan kerja yang mencakup dimensi lingkungan fisik, lingkungan perantara, metode kerja dan pengaturan kerja sudah mulai sesuai kebutuhan perbankan syariah sehingga dapat menopang untuk meningkatkan kualitas produk layanan perbankan syariah Kota Sukabumi.

2. Perencanaan tenaga kerja dan Lingkungan kerja terhadap kualitas produk layanan

Berdasarkan uji koefesien determinasi, dapat dilihat bahwa nilai $r$ square menunjukkan angka sebesar 0,539 atau $53,9 \%$ maka dapat dinyatakan 
bahwa perencanaan tenaga kerja dan lingkungan kerja terhadap kualitas produk layanan memiliki pengaruh sebasar $53,9 \%$ atau dapat disimpulkan variabel perencanaan tenaga kerja dan lingkungan kerja terhadap kualitas produk layanan mempunyai pengaruh sedang. Maka dengan demikian apabila perencanaan tenaga kerja dan lingkungan kerja ditingkatkan maka kualitas produk layanan dapat meningkat.

\section{Kesimpulan dan Saran Kesimpulan}

Berdasarkan hasil penelitian dan pembahasan penelitian yang berjudul pengaruh perencanaan tenaga kerja dan lingkungan kerja terhadap kualitas produk layanan Bank Syariah yang ada di Kota Sukabumi, sehingga dengan demikian dapat ditarik simpulan sebagai berikut:

a. Perencanaan tenaga kerja terhadap kualitas produk layanan mempunyai pengaruh yang lemah.

b. Lingkungan kerja terhadap kualitas produk layanan mempunyai pengaruh sedang.

c. Perencanaan tenaga kerja dan Lingkungan kerja terhadap kualitas produk layanan mempunyai pengaruh sedang.

\section{Saran}

a. Untuk meningkatkan kualitas produk layanan agar ditingkatkan perencanaan tenaga kerja dengan cara rekrutment dan seleksi karyawan sesuai kebutuhan tenaga kerja, bekerjasama dengan lembaga pendidikan yang meluluskan diploma maupun sarjana-sarja perbankan syariah, melakukan pelatihan dan pengembangan kepada calon karyawan sebelum mereka siap untuk bekerja, adanya perencanaan karier mulai dari jengjang karier yang paling rendah sampai yang paling tinggi agar kemampuan karyawan untuk bekerja telah memenuhi persyaratan yang dipersyaratkan sebelumnya. b. Lingkungan kerja agar tetap ditingkatkan agar dapat meningkatkan kualitas produk layanan.

c. Perencanaan tenaga kerja dan lingkungan kerja harus ditingkatkan agar dapat meningkat kualitas produk layanan

\section{REFERENSI}

Aaker, David, 1991, Managing Brand Equity; Capitalizing on the Value of Brand Name, Free Press, New York

Alex S. Nitisemito, 2000, Manajemen Pemasaran, Ghalia Indonesia, Jakarta

Anwar Prabu Mangkunegara. 2003, Perencanaan dan Pengembangan Sumber Daya Manusia, Bandung, Refika Aditama

Garvin, David, "Managing Quality", di dalam Nasution, M.N. 2001. Manajemen Mutu Terpadu (Fotal Quality Management). Jakarta: Ghalia Indonesia

Handoko, T. Hani. 1997. Manajemen dan Sumber Daya Manusia. Yogyakarta: Penerbit Liberty

Hermawan Kartajaya,Muhhammad Syakir Sula, Syariah Marketing, (Bandung, Mizan Media Utama, 2006)

Keller, Kevin Lane. 1998. Strategic Brand Management, Building, Measuring, and Managing Brand Equity. New Jersey : Prentice Hall

Mathis, Robert. L \& Jackson John. H, 2001. Manajemen Sumber Daya Manusia, Jilid 1, Salemba Empat, Jakarta

Sedarmayanti. 2009. Sumber Daya Manusia dan Produktivitas Kerja. Bandung: CV Mandar Maju

Schultz, Duane P dan Schultz (2007), Working Condition and Work Today. Sixth Edition, Willey and Sons, Inc

Sugioyono, 2013. Cara Mudah menyusun skripsi, Tesis dan Disertasi. Yogyakarta : Alfabeta.

Tarsidin, Bagi Hasil: Konsep dan Analisis, (Jakarta: Lembaga Penerbit Fakultas Ekonomi, 2010) 
Umar Husein, Riset Pemasaran dan Prilaku Konsumen (Jakarta: PT. Gramedia, 2002)

Umer Chapra, Masa Depan Ilmu Ekonomi, Sebuah Tinjauan Islam (Jakarta, Gema Insani Press, 2001)

Yoder, Dale, 1981, Personnel Management and industrial relation, New Delhi Prentice Hall of indian private Limited 